\title{
Loteprednol Etabonate
}

National Cancer Institute

\section{Source}

National Cancer Institute. Loteprednol Etabonate. NCI Thesaurus. Code C47589.

The etabonate salt form of loteprednol, an ophthalmic analog of the corticosteroid prednisolone with anti-inflammatory activity. Loteprednol etabonate exerts its effect by interacting with specific intracellular receptors and subsequently binds to DNA to modify gene expression. This results in an induction of the synthesis of certain anti-inflammatory proteins while inhibiting the synthesis of certain inflammatory mediators. Loteprednol etabonate specifically induces phospholipase A2 inhibitory proteins (collectively called lipocortins), which inhibit the release of arachidonic acid, thereby inhibiting the biosynthesis of potent mediators of inflammation, such as prostaglandins and leukotrienes. 